\title{
Development of Digital Instruction as a Guide in Wushu Training
}

\author{
Rusmono $^{1, *}$, Jarudin ${ }^{2}$, Prajka Ibnu Khuzaimah ${ }^{3}$ \\ ${ }^{1}$ Department of Education Technology, Universitas Negeri Jakarta, Indonesia \\ ${ }^{2}$ Department of Information Technology, Faculty of Computer Science, STMIK Bina Sarana Global, Indonesia \\ ${ }^{3}$ Department of Aerospace Technique, Faculty of Technical Engineering, Institut Teknologi Bandung, Indonesia
}

Received October 24, 2019; Revised January 21, 2020; Accepted February 25, 2020

Copyright $\bigcirc 2020$ by authors, all rights reserved. Authors agree that this article remains permanently open access under the terms of the Creative Commons Attribution License 4.0 International License

\begin{abstract}
The instructional process should be based on principles, centered on the trainees, developing the creativity of trainees, creating fun and challenging conditions, developing a variety of value-rated capabilities, providing a diverse learning experience, and learning through doing. Technology has a positive effect not only on social life but also on education. The purpose of this study is to develop digital instruction as a guide in learning Wushu to improve skills. The methodology used was research and development. The instrument used was a questionnaire using the Likers scale. The instrument validation is carried out by media experts, design, and instructional materials. The results of the feasibility of this development that digital instruction based on expert validation has an average score of $92 \%$, which means that the product is produced to be used. The effectiveness of results based on field trials with pre and post test results has increased by 1.5 units, meaning that this product is effective in improving skills. Based on validation and effectiveness test, digital instruction was very effective as a guide in learning Wushu. Digital instruction is a support for the training instructional process so that they can develop appropriate and innovative instructional media to facilitate trainees who participated. The impact of this study is that an innovative instruction can effectively improve skills of Wushu trainees.
\end{abstract}

Keyword Digital Instruction, Guide in Practice, Wushu Instructional

\section{Introduction}

The instructional process should be based on principles, centered on the trainees, developing the creativity of trainees, creating fun and challenging conditions, developing a variety of value-rated capabilities, providing a diverse learning experience, and learning through doing (Jarudin, Ibrahim, \& Muslim, 2018). The effectiveness of digital learning over the in-class instruction(Kirovskasimjanoska, 2016). Students' own beliefs about digital literacy development may have profound impacts on their behaviors in learning situations where digital literacy is required (List, 2019).

Digital technologies are prevalent today thanks to the diffusion of a digital culture, which integrates them into a meaningful way of life (Guy, 2019). Digitally literacy includes the ability to use and understand present digital technologies, as well as anticipate future digital technologies (Hamilton, 2019). The potential benefits of digital technology for teaching and learning in schools have been extensively characterized in the academic literature (Badia, Meneses, Sigalés, \& Fàbregues, 2014). According to Bilbao-Osorio \& Pedró (2009), two types of the positive impacts of digital technologies can be identified: (i) the enhancement of the student performance, which includes aspects such as the development of ICT competences and the academic performance in basic subjects, and (ii) the improvement and introduction of new processes of teaching and learning (Bilbao-Osorio \& Pedró, 2009). Digital training can also provide content that is tailored to the abilities, interests, and values of individual (Mrazek et al., 2018).

Media-enhanced teaching has become popular and has been implemented at many German universities. Digital teaching styles appeal to the new generation of students at universities (Generation Y) who have been exposed to the internet and mobile communication all their lives, and who often prefer blended learning approaches (a combination of digital media and conventional classroom methods) over traditional lectures or e-learning alone(Bock et al., 2018).

Media literacy is not only the simple development of interpretive skills but also involves a series of digital production skills that include "the ability to create, to be critical and to contribute as well as to consume" (Flew, 
2014). Digital literacy programs must go beyond training or teaching the basic ICT skills of how to use the technology and include the context of where and when to apply the skills, knowledge, and information (Cress et al., 2018). Therefore, the participant needs the confidence to operate safely in a digital environment. Digital media is accessed, consumed, created, modified, shared, used, or interacted with on a constantly evolving set of technology platforms (Dalope \& Woods, 2018; Ruest, Gjelsvik, Rubinstein, \& Amanullah, 2018).

Electronic learning media in technology-enhanced and student-centered learning environments can facilitate the learning and understanding of abstract concepts now that students can notice graphically displayed changes in concrete experience (Eriksson, Swenberg, Zhao, \& Eriksson, 2018; Knez, Stevanovic, Vulić-Prtorić, VlašićCicvarić, \& Peršić, 2015; Sangsawang, 2015). The use of digital media for trainees-instructor communication is increasing (Bordalba \& Bochaca, 2019). However, many trainees and instructor are still reluctant to use such media to enhance two-way pedagogical communication between trainees and instructor(Bordalba \& Bochaca, 2019). This paper explores the trainees' and instructor beliefs regarding the use of e-module and online platforms for two-way communication.

In e-learning, a learning object is the use of the digital document in the e-learning containing both audio-visual media and interactive exercises consequently to create the learning experience (Darmadi, Liawatimena, Abbas, \& Trisetyarso, 2018). In media contexts, a feigned choice might be sufficient to evoke an increase in autonomy, motivation and learning performance without losing credibility. New technologies often promise an individualization of learning processes. In addition, the learning relevance of choice options is still questionable, so that even learning-irrelevant choice options, like different genres of background music, might be helpful in enhancing the learners' motivation (Schneider, Nebel, Beege, \& Rey, 2018).

Online instructional formats such as e-modules and computer-based simulation programs are known to enhance knowledge, skills, offer flexible, and costeffective learning opportunities(Dankbaar et al., 2017; Howard \& Mozejko, 2015). Technologies are the potential tools for instructors to motivate and to engage their students in learning. For instance, it will help students improve their learning skills such as drills and practices, information inquiry, participatory learning, and enhancing their responsibilities(Phosuwan, Sopeerak, \& Voraroon, 2013). Technology has a positive effect not only on social life but also on education. Due to the continuous integration of technology into educational settings, educators are expected, as a matter of urgency, to utilize digital tools to support classroom teaching and learning (Akyuz \& Yavuz, 2015)

Wushu is both full contact and performing sport. Wushu is derived from Chinese martial arts and it teaches (WuDe), which is the martial code of conduct(Judkins, 2014; Sport, 2014). Wushu is the national game of China. It is one of the disciplines of Asian Games and Wushu is on the docket to become an Olympic sport and it was also an exhibition sport in the 2008 Beijing Olympic Games. The beginning of Chinese martial arts is really hard to trace. Most probably it all started as tribal skirmishes or battles which, eventually modifies and various techniques were introduced to make it more effective and complex. From these battles, experiences were accumulated and new techniques were discovered which were passed down generation to generation(Kumar \& Mishra, 2015).

Wushu is a sport that works throughout the body and helps a person stay active. Wushu helps develop strength, flexibility, coordination, strength, speed and balance(Yuwono \& Setiawan, 2014). The learning objectives, course demand, and assessment procedures were very explicit and very similar to the conventional programmes delivered on campus. Learning materials were designed for individual use( $\mathrm{Li}, 2017)$. Learning is also the basis for future progress in society. The development produced by individuals that evolve from their learning and ingenuity contributes to new discoveries and inventions by subsequent generations(Gredler, 2009). The purpose of this study is to develop digital instruction as a guide to learning Wushu in improving skills, with an effective, efficient and enjoyable instructional system.

\section{Method}

This research used in this study is Research and Development (R \& D). This research was conducted with a sample of 30 training participants divided into three groups, three training participants for one to one test, eight small group test participants, and 19 field test participants. The instrument used was a questionnaire. Data analysis uses average values. The dataset can be accessed on Open Science Framework osf.oi / fmeah("Open science Framwork," n.d.) .

\section{Results and Discussion}

The results of this study produce innovative digital instruction that can improve the competency results of trainees by using systematically designed instructional digital for guiding learning participants; the media used has been revised based on the expert team's assessment and tested through the One to One stage, Small group try-out and field trial. The results of these trials can be described as follows:

\subsection{One to one Try-outs}

One-to-one try-outs were conducted between 
instructional developers and three trainees individually. At the end of the one to one trial, a test will be given to be able to measure the level of understanding of digital instruction that is seen and practiced, while the results of the trial data on three trainees are presented in table 1.

Table 1. Results of One to one Test Assessment

\begin{tabular}{|c|c|c|}
\hline Respondents & Values & Alphabet \\
\hline Respondent 01 & 84,0 & B \\
\hline Respondent 02 & 84,5 & B \\
\hline Respondent 03 & 87,1 & A \\
\hline Average & 85,2 & A \\
\hline
\end{tabular}

The results of individual trials illustrate that the average value of 85.2 means that the quality of trials in this range is in the feasible category. Based on the average value it can be said that the digital instruction developed can be used as instructional materials to achieve competence and understanding of Wushu training material. In the opinion of Suwana and Lily, digital media as a guide in skills improvement training(Suwana \& Lily, 2017). Also supported by opinion Dalope and Woods, digital media helps increase skills in training(Dalope \& Woods, 2018). Also supported by the opinions of Iconaru and Ciucurel, emodules serve as a tool in training(Iconaru \& Ciucurel, 2014).

\subsection{Small Group Try-outs}

Therefore, the conclusion of the results of the small group trials did not experience much change in the digital instruction both material and instructional. The following are the results of the tests conducted after the end of the small group trials which can be illustrated in the following table 2:

Table 2. Results of Small Group Test Assessment

\begin{tabular}{|c|c|c|}
\hline Respondents & Values & Alphabet \\
\hline Respondent 01 & 88,3 & A \\
\hline Respondent 02 & 86,5 & A \\
\hline Respondent 03 & 85,4 & A \\
Respondent 04 & 79,9 & B \\
Respondent 05 & 86,7 & A \\
Respondent 06 & 84,6 & B \\
Respondent 07 & 85,5 & A \\
Respondent 08 & 83,8 & B \\
\hline Average & 85,1 & A \\
\hline
\end{tabular}

From the data from the test results of the small group test with the acquisition of the value of the training participants on average 85,1 with good criteria, it illustrates that the digital instructional is very feasible for major trials or field trials. It's just that as a constant consideration the developer coordinates with the Wushu training instructor. This opinion is supported by Lewis's research that instructional media can improve students' competence (Lewis, 2013). Also supported by the research of Steve et. al., that the use of instructional media in training can guide participants in independent learning (Steve, 2015) and is also supported by Jin opinion that the media not only produce learning effects but also enhance the participants' independent learning abilities (Jin, 2017).

\subsection{Field Trials}

The trial was conducted with 19 trainees, adjusted for the number of trainees who entered the beginner class, namely for the yellow belt in 2018. The main trial process was carried out like a small group trial it's just that the population or number of trainees is more than the small group trials.

The comparison of the results of the initial and final test results of this field trial can be seen in the following table 3.

Table 3. Pre-test Results and Post-test Field Trials

\begin{tabular}{|c|c|c|c|c|}
\hline Respondents & Pre-test & Alphabet & Post-test & Alphabet \\
\hline Respondent 01 & 73,7 & C & 83,9 & B \\
\hline Respondent 02 & 81,0 & B & 86,0 & A \\
\hline Respondent 03 & 79,9 & B & 85,8 & A \\
Respondent 04 & 71,5 & C & 80,9 & B \\
Respondent 05 & 85,3 & A & 88,0 & A \\
Respondent 06 & 85,1 & A & 87,5 & A \\
Respondent 07 & 81,9 & B & 85,5 & A \\
Respondent 08 & 82,0 & B & 86,8 & A \\
Respondent 09 & 74,5 & C & 83,9 & B \\
Respondent 10 & 75,8 & B & 84,7 & B \\
Respondent 11 & 82,7 & B & 86,7 & A \\
Respondent 12 & 81,5 & B & 85,8 & A \\
Respondent 13 & 79,1 & B & 84,9 & B \\
Respondent 14 & 81,9 & B & 85,7 & A \\
Respondent 15 & 82,6 & B & 86,3 & A \\
Respondent 16 & 82.1 & B & 86,2 & A \\
Respondent 17 & 81,9 & B & 86,0 & A \\
Respondent 18 & 81,5 & B & 85,3 & A \\
Respondent 19 & 81,0 & B & 85,1 & A \\
\hline Average & 75,9 & B & 85,5 & A \\
\hline
\end{tabular}

Based on table 3 above, the presentation of the results of the field trial pre-test can be see Figure 1 below.

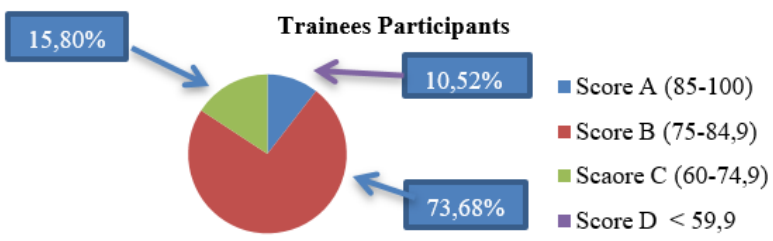

Figure 1. Pre-test Results Field Trials

Based on the picture above, the results of the field trials on 19 Wushu trainees participants showed that the trainees participants scored $85-100$ (A) as much as $10.52 \%$, trainees participants who scored $75-84.9$ (B) as much as $73.68 \%$, trainees participants who gained 60-74.9 (C) were $15.80 \%$ while those of 50-59.99 (D) was 0\%. It can be concluded that $15,80 \%$ of the trainees participants got the $\mathrm{C}$ value of 
this result indicating an incomplete understanding of the material.

Based on table 3 above, the presentation of the results of the post-test field trials can be seen in Figure 2 below.

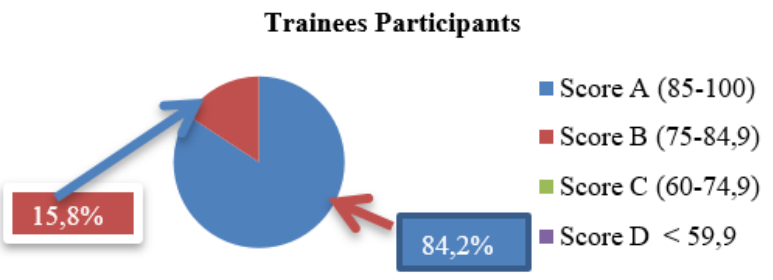

Figure 2. Post-test Results Field Trials

Based on table 3 above, the results of the field trial test for 19 trainees participants showed that the trainees participants who scored 85-100 (A) were 84.2\%; the trainees who received $75-84.9$ (B) were $15.8 \%$; trainees participants who obtained 60-74.99 (C) as much as $0 \%$, and trainees participants who gained $>59.99$ as much as $0 \%$. It can be concluded that all $100 \%$ trainees who participated found that the $\mathrm{A}$ and $\mathrm{B}$ values showed a complete understanding of the material.

Based on the results of the pre-test and the post-test on the field trials showed an increase in the results of the test post, so it can be concluded that learning with digital instruction can improve the skills of trainees and the feasibility used in Rajawali Sakti Wushu training branch MAG Jakarta. Research is supported by researchers Sousa and Rocha (2019) Digital learning can be a driver for skills development (Sousa \& Rocha, 2019). Also supported by researchers Hawlitschek and Joeckel (2017) Digital media can motivate students to improve skills (Hawlitschek \& Joeckel, 2017), and Participants increased their performance and satisfaction with performance on digital media (Raghavendra, Hutchinson, Grace, Wood, \& Newman, 2018). Students increasingly need to learn content and perspectives that are not given as part of the curriculum. Students need to establish additional forms of supports and scaffolds for learning with digital media (Ludvigsen, Cress, Rosé, Law, \& Stahl, 2018). Digital media learners successfully handling disturbances in the form of solving socio-cognitive conflicts and productive friction are indispensable for learning and knowledge construction (Holtz, Kimmerle, \& Cress, 2018).

\section{Conclusions}

The results of this study can be concluded that the development of independent digital instruction for Wushu training shows an increase in the skills of Wushu trainees participants using independent instructional media. It is suggested to other researchers, to develop further, so that development does not only produce digital instruction products but also provides another significant contribution to instructional. Socialization is held to other instructors in using instructional methods using media as a support for the training instructional process so that they can develop appropriate and innovative instructional media to facilitate trainees who participated.

\section{Acknowledgements}

I would like to express my gratitude to my team research. Also, I would like to thank the participants in my survey, who have willingly shared their precious time during the process of collecting data. Thank you, my wife, for their endless love.

\section{REFERENCES}

[1] Akyuz, S., \& Yavuz, F. (2015). Digital Learning in EFL Classrooms. Procedia - Social and Behavioral Sciences, 197 (February), 766-769. https://doi.org/10.1016/j.sbspro. 2015.07.176

[2] Badia, A., Meneses, J., Sigalés, C., \& Fàbregues, S. (2014). Factors Affecting School Teachers ' Perceptions Of The Instructional Benefits Of Digital Technology. Procedia Social and Behavioral Sciences, 141, 357-362. https://doi.org/10.1016/j.sbspro.2014.05.063

[3] Bilbao-Osorio, B., \& Pedró, F. (2009). A theoretical analysis for studying the impact of information technology in education in latin america. Assessing the Effects of ICT in Education, 107-118. Retrieved from www.scielo.org.co/sc ielo.php?script=sci_nlinks

[4] Bock, A., Modabber, A., Kniha, K., Lemos, M., Rafai, N., \& Hölzle, F. (2018). Blended learning modules for lectures on oral and maxillofacial surgery. British Journal of Oral and Maxillofacial Surgery, 6. https://doi.org/10.1016/j.bjoms.2 018.10.281

[5] Bordalba, M. M., \& Bochaca, J. G. (2019). Digital media for family-school communication? Parents' and teachers' beliefs. Computers \& Education, 132, 44-62. https://doi.org/10.1016/j.compedu.2019.01.006

[6] Cress, U., Stahl, G., Rose, C., Law, N., Ludvigsen, S., Sousa, M. J., ... Christiaens, T. (2018). Issues and Trends in Instructional Technology: Consistent Growth in Online Learning, Digital Content, and the Use of Mobile Technologies. In: Branch R. (eds) Educational Media and Technology Yearbook. Educational Media and Technology Yearbook, Springer, Cham, 17(1), 61-71. https://doi.org/10.1007/978-3-319-67301-1_5

[7] Dalope, K. A., \& Woods, L. J. (2018). Digital Media Use in Families: Theories and Strategies for Intervention. Child and Adolescent Psychiatric Clinics of North America, 27(2), 145-158. https://doi.org/10.1016/j.chc.2017.11.001

[8] Dankbaar, M. E. W., Richters, O., Kalkman, C. J., Prins, G., Ten Cate, O. T. J., Van Merrienboer, J. J. G., \& Schuit, S. C. E. (2017). Comparative effectiveness of a serious game and an e-module to support patient safety knowledge and awareness. BMC Medical Education, 17(1), 1-10. 
https://doi.org/10.1186/s12909-016-0836-5

[9] Darmadi, H., Liawatimena, S., Abbas, B. S., \& Trisetyarso, A. (2018). ScienceDirect ScienceDirect Hypermedia Driven Application Programming Interface for Hypermedia Driven Application Programming Interface for Learning Object Management Learning Object Management. Procedia Computer Science, 135, 120-127. https://doi.org/10.1016/j.procs.2018.08.157

[10] Eriksson, P. E., Swenberg, T., Zhao, X., \& Eriksson, Y. (2018). How gaze time on screen impacts the efficacy of visual instructions. Heliyon, 4(6). https://doi.org/10.1016/j. heliyon.2018.e00660

[11] Flew, T. (2014). New media: An introduction (4th ed., Vol. 31). Melbourne, VIC, Australia: Oxford University Press.

[12] Gredler, M. (2009). Learning Instruction Theory Into Practice 6Th Edition (6th ed.). New Jersey: Pearson. Retrieved from https://mudarwan.files.wordpress.com/201 5/08/learning-instruction-theory-into-practice-6th-editionmargaret_e-_gredler_2009.pdf

[13] Guy, J. (2019). Technological Forecasting \& Social Change Digital technology, digital culture and the metric / nonmetric distinction. Technological Forecasting \& Social Change, 145(May), 55-61. https://doi.org/10.1016/j.techfo re.2019.05.005

[14] Hamilton, S. (2019). Re fl ection ( s ) In / On Digital Writing ' s Hybrid Pedagogy , 2010 - 2017, 52, 158-174. https://doi.org/10.1016/j.compcom.2019.02.006

[15] Hawlitschek, A., \& Joeckel, S. (2017). Increasing the effectiveness of digital educational games: The effects of a learning instruction on students' learning, motivation and cognitive load. Computers in Human Behavior, 72, 79-86. https://doi.org/10.1016/j.chb.2017.01.040

[16] Holtz, P., Kimmerle, J., \& Cress, U. (2018). Using big data techniques for measuring productive friction in mass collaboration online environments. International Journal of Computer-Supported Collaborative Learning, 439-456. https://doi.org/10.1007/s11412-018-9285-y

[17] Howard, S. K., \& Mozejko, A. (2015). Teachers: technology, change and resistance. Teaching and Digital Technologies: Big Issues and Critical Questions, 307-317. https://doi.org/10.1111/bjet.12139

[18] Iconaru, E. I., \& Ciucurel, C. (2014). Developing Social and Civic Competencies in People with Intellectual Disabilities from a Family Center through an Adapted Training Module. Procedia - Social and Behavioral Sciences, 116, 3303-3307. https://doi.org/10.1016/j.sbspro.2014.01.752

[19] Jarudin, Ibrahim, N., \& Muslim, S. (2018). Develop SelfDirected Instructional Media for Wushu Training. International Journal of Science and Research (IJSR), 7(11), 1748-1754. https://doi.org/10.21275/ART20193137

[20] Jin, Z. (2017). A constructivism-based 3d scene display teaching system for Wushu teaching. International Journal of Emerging Technologies in Learning, 12(1), 84-94. https://doi.org/10.3991/ijet.v12i01.6485

[21] Judkins, B. (2014). Inventing Kung Fu. Journalism, Media and Cultural Studies, 5, 1-23. https://doi.org/10.18573/j.2014.10272
[22] Kirovska-simjanoska, D. (2016). Do ESP Students Prefer Face-To-Face Instruction Over Digitally Embedded Instruction? Blogs vs . Reports? Debates vs . Online Discussion? Procedia - Social and Behavioral Sciences, 232(April), 170-176. https://doi.org/10.1016/j.sbspro.2016 .10 .042

[23] Knez, R., Stevanovic, D., Vulić-Prtorić, A., Vlašić-Cicvarić, I., \& Peršić, M. (2015). The Croatian Version of the Pediatric Quality of Life Inventory (PedsQL ${ }^{\mathrm{TM}}$ ) Family Impact Module: Cross-Cultural Adaptation and Psychometric Evaluation. Journal of Child and Family Studies, 24(2), 363-371. https://doi.org/10.1007/s10826013-9844-9

[24] Kumar, D., \& Mishra, S. R. (2015). Introduction to Chinese Martial Arts "WUSHU ". International Education and Research Journal, 1(4), 16-20. Retrieved from tps://www.academia.edu/18784370/Introduction_to_Chine se_Martial_Arts_WUSHU_

[25] Lewis, F. (2013). Introduction to Self-Directed Learning. William Carey International Development Journal, 2(1), 17. Retrieved from www.wciujournal.org

[26] Li, Z. (2017). Learners' reflexivity and the development of an e-learning community among students in China. ALT-J: Research in Learning Technology, 19(1), 5-17. https://doi.org/10.1080/09687769.2010.548505

[27] List, A. (2019). Defining digital literacy development: An examination of pre-service teachers' beliefs. Computers and Education.https://doi.org/10.1016/j.compedu.2019.03. 009

[28] Ludvigsen, S., Cress, U., Rosé, C. P., Law, N., \& Stahl, G. (2018). Developing understanding beyond the given knowledge and new methodologies for analyses in CSCL. International Journal of Computer-Supported Collaborative Learning, 359-364. https://doi.org/10.1007/ s11412-018-9291-0

[29] Mrazek, A. J., Michael, M. D., Casey M Cherolini, Jonathan N Cloughesy, D. J. C., Gougis, L. J., Landry, A. P., ... Schooler, J. W. (2018). The Future of Mindfulness Training Is Digital, and The Future is Now. Current Opinion in Psychology, 1-17. https://doi.org/10.1016/j.copsyc.2018.1 1.012

[30] Open science Framwork. (n.d.). Retrieved from https://osf.oi/fmeah

[31] Phosuwan, A., Sopeerak, S., \& Voraroon, S. (2013). Factors Related the Utilization of Instructional Media and Innovation of Nursing Instructors at Boromarajonani College of Nursing, Suphanburi, Thailand. Procedia Social and Behavioral Sciences, 103, 410-415. https://doi.org/10.1016/j.sbspro.2013.10.354

[32] Raghavendra, P., Hutchinson, C., Grace, E., Wood, D., \& Newman, L. (2018). "I like talking to people on the computer": Outcomes of a home-based intervention to develop social media skills in youth with disabilities living in rural communities. Research in Developmental Disabilities, 76(December 2017), 110-123. https://doi.org/10.1016/j.ridd.2018.02.012

[33] Ruest, S., Gjelsvik, A., Rubinstein, M., \& Amanullah, S. (2018). The Inverse Relationship between Digital Media Exposure and Childhood Flourishing. Journal of Pediatrics, 
197, 268-274.e2. https://doi.org/10.1016/j.jpeds.2017.12.0 16

[34] Sangsawang, T. (2015). Instructional Design Framework for Educational Media. Procedia - Social and Behavioral Sciences, 176, 65-80.https://doi.org/10.1016/j.sbspro.2015 .01 .445

[35] Schneider, S., Nebel, S., Beege, M., \& Rey, G. D. (2018). The autonomy-enhancing e ff ects of choice on cognitive load, motivation and learning with digital media. Learning and Instruction, 58(June), 161-172. https://doi.org/10.101 6/j.learninstruc.2018.06.006

[36] Sousa, M. J., \& Rocha, Á. (2019). Digital learning: Developing skills for digital transformation of organizations. Future Generation Computer Systems, 91, 327-334. https://doi.org/10.1016/j.future.2018.08.048

[37] Sport, S. (2014). Safe Wushu Guide, 16. Retrieved from http://www.sportsingapore.gov.sg/sports-education/sportssafety

[38] Steve, O. (2015). Constructivism Learning Theory: A Paradigm for Teaching and Learning. IOSR Journal of Research \& Method in Education Ver. I, 5(6), 66-70. https://doi.org/10.9790/7388-05616670

[39] Suwana, F., \& Lily. (2017). Empowering Indonesian women through building digital media literacy. Kasetsart Journal of Social Sciences, 38(3), 212-217. https://doi.org/10.1016/j.kjss.2016.10.004

[40] Yuwono, Y., \& Setiawan, A. P. (2014). Interior Design of Wushu Training and Information Centers in Surabaya. Jurnal Intra, 2(2), 81-86. 